OPEN ACCESS

Citation: Jing Ma, Wenyan Fan, Shujun Jiang, Xiling Yang, Wenshuai Li, Di Zhou, Amir Abbas Minaeifar (2021) Molecular techniques in the assessment of genetic relationships between populations of Consolida (Ranunculaceae). Caryologia 74(2): 149-161. doi: 10.36253/caryologia-1235

Received: March 05, 2021

Accepted: July 20, 2021

Published: October 08, 2021

Copyright: @2021 Jing Ma, Wenyan Fan, Shujun Jiang, Xiling Yang, Wenshuai Li, Di Zhou, Amir Abbas Minaeifar. This is an open access, peer-reviewed article published by Firenze University Press (http://www.fupress.com/caryologia) and distributed under the terms of the Creative Commons Attribution License, which permits unrestricted use, distribution, and reproduction in any medium, provided the original author and source are credited.

Data Availability Statement: All relevant data are within the paper and its Supporting Information files.

Competing Interests: The Author(s) declare(s) no conflict of interest.

\section{Molecular techniques in the assessment of genetic relationships between populations of Consolida (Ranunculaceae)}

\author{
Jing MA ${ }^{1}$, Wenyan FAN ${ }^{1, *}$, Shujun JiAng ${ }^{1}$, Xiling YAng ${ }^{1}$, Wenshuai Li ${ }^{1}$, Di \\ $\mathrm{ZHOU}^{1}$, Amir ABbas MinaEIFAR ${ }^{2, *}$ \\ 1. Agronomy College, Heilongjiang Bayi Agricultural University, Daqing, Heilongjiang, \\ 163319, China \\ ${ }^{2}$ Department of Biology, Payame Noor University, P.O. Box19395-3697 Tehran, Iran \\ Corresponding author. E-mail: fwyjsj2021@126.com; aaminaeifar@pnu.ac.ir
}

\begin{abstract}
Genetic diversity studies are essential to understand the conservation and management of plant resources in any environment. The genus Consolida (DC.) Gray (Ranuculaceae) belongs to tribe Delphinieae. It comprises approximately 52 species, including the members of the genus Aconitella Spach. No detailed Random Amplified Polymorphic DNA (RAPD) studies were conducted to study Consolida genetic diversity. Therefore, we collected and analyzed 19 species from 12 provinces of regions. Overall, one hundred and twenty-seven plant specimens were collected. We showed significant differences in quantitative morphological characters in plant species. Unweighted pair group method with arithmetic mean and principal component analysis (PCA) divided Consolida species into two groups. All primers produced polymorphic amplicons though the extent of polymorphism varied with each primer. The primer OPA06 was found to be most powerful and efficient as it generated a total of 24 bands of which 24 were polymorphic. The Mantel test showed correlation $(r=0.34, p=0.0002)$ between genetic and geographical distances. We reported high genetic diversity, which clearly shows the Consolida species can adapt to changing environments since high genetic diversity is linked to species adaptability. Present results highlighted the utility of RAPD markers and morphometry methods to investigate genetic diversity in Consolida species. Our aims were 1) to assess genetic diversity among Consolida species 2) is there a correlation between species genetic and geographical distance? 3) Genetic structure of populations and taxa.
\end{abstract}

Keywords: Consolida, population structure, gene flow, network, genetic admixture.

\title{
INTRODUCTION
}

Genetic diversity is a vital feature that helps plant species survive in an ever-changing environment, and it sheds light on understanding the phylogenetic affinity among the species (Erbano et al. 2015; Ellegren and Galtier 2016; Turchetto et al. 2016 ). Quite a significant number of genetic resources and materials programs of plant species have been carried out to preserve 
the plant species worldwide. Scientific data indicate that genetic diversity plays a pivotal role in conservation programs (Gomez et al. 2005; Frankham 2005; Cires et al. 2013).

The genus Consolida (DC.) Gray (Ranuculaceae) belongs to tribe Delphinieae. It comprises approximately 52 species, including the members of the genus Aconitella Spach. Iran is one of the richest countries for the genus in South-West Asia, since it has 24 species (Iranshahr et al., 1992).

The genus Consolida S.F. Gray was considered as a separate genus based on one species (C. regalis) by Gray (1821), who worked on British flora. But some researchers considered Consolida as a section of Delphinium (De Candole 1824; Boissier 1867; Huth 1895; Nevskii 1937). Unlike the others based on annual life form, single spured petal, single follicle compared to 3 or 5 sessile follicles of Delphinium recognized Consolida as a separate genus (Tutin et al. 1964; Davis 1965; Munz 1967; Hayek 1970; Iranshahr 1992; Ertugrul et al. 2016; Khalaj 2013). Kemularia-Nathades (1939) recognized a new genus Aconitopsis from species of Consolida based on peculiar formation of the petal, upper sepal, and spur. The name Aconitopsis was later rejected by Sojak (1969) and being replaced by Aconitella because of nomenclature priority. Some researchers have studied these genera taxonomically (Soo 1922; Munz 1967 ; Davis 1965; Iranshahr et al., 1992; Constantinidis et al., 2001). Consolida has about 40 species, of which 19 have been recorded from Iran. Aconitella with ca. 10 species (3 species in Iran) and 31 species of Delphinium (species in Iran) are centred in Irano-Turanian and Mediterranean phytogeographic regions (Trifonova, 1990; Hasanzadeh et al. 2017).

Consolida has been separated from Delphinium by De Candolle based on single spurred petals, one follicle and annual life cycle and has occurred in separate section. Finally, it introduced as a separate genus by Gray in 1821 (Triffonova, 1990). Based on phylogenetic studies of Jabbour and Renner (2011), Aconitella is part of Consolida, both being embedded in Delphinium. The Jabbour \& Renner (2011) results showed that Consolida diverged from Delphinium relatives in the Early to Middle Miocene, a period of increasing aridity, caused primarily by decrease in sea level in the Mediterranean (Hayek 1970; Iranshahr 1992; Ertugrul et al. 2016) and desertification in Asia (Triffonova 1990).

Some biosystematic studies have carried out in various field such as chromosomal studies (Trifonova 1990; Koeva 1992; Hong, 1986) chemical studies (Aitzetmuller et al.1999), palynological studies (Munz, 1967) and phylogenetic investigations by using DNA sequence data (Johansson 1995; RO et al.1997; Jabbour and Renner 2011; 2012; Yosefzadeh et al. , 2012). In the recent molecular studies (Jabbour and Renner 2001; 2012) it was showed that Consolida and Aconitella form a clade embeded in Delphinium and also Aconitella is embedded within Consolida. The Jabbour and Renner (2011) results showed that Consolida diverged from Delphinium relatives at least in the early of middle Miocene.

Genetic diversity studies are usually tapped due to molecular markers. Molecular markers are an excellent method to disentangle phylogenetic association between species and population. Among molecular methods or markers, RAPD (Random Amplified Polymorphic DNA) are sensitive to detect variability among individuals of species. RAPD method is cost-effective and can work with limited sample quantities. In addition to this, RAPD can amplify and target genomic regions with potential and several markers (Esfandani-Bozchaloyi et al. 2017a). Taxonomical Systematics studies were conducted in the past to identify the Consolida species. According to the best of our knowledge, there is no existing RAPD data on genetic diversity investigations in Iran. We studied one hundred and twenty-seven samples. Our aims were 1) to assess genetic diversity among Consolida species 2) is there a correlation between species and geographical distance? 3) Genetic structure of populations and taxa 4) Are the Consolida species able to exchange genes?

\section{MATERIALS AND METHODS}

\section{Plant materials}

19 Consolida species were collected from different regions of Iran (Table 1). These species were studied via morphological and molecular methods. 127 plant samples (10-25 per plant species) were examined for morphometry purposes (Figure 1). The random amplified polymorphic DNA analysis method was limited to 110 samples. According to previous references, all the species were identified (Iranshahr, 1992; Ertugrul et al., 2016; Khalaj, 2013). Voucher specimens were deposited in Herbarium of Azad Islamic University (HAIU).

\section{Morphometry}

We studied 18 qualitative and 7 quantitative morphological characters (Table 2). Data were transformed (Mean $=0$, variance $=1$ ) prior to ordination . Euclidean distance was implemented to cluster and ordinate plant species (Podani 2000). 
Table 1. Location and herbarium accession numbers of the studied populations of Consolida species collected by Mehri in Iran.

\begin{tabular}{|c|c|c|c|c|}
\hline No & Sp. & Locality & Latitude Longitude & $\begin{array}{l}\text { Altitude } \\
\quad(\mathrm{m})\end{array}$ \\
\hline Sp1 & C. tehranica (Boiss.) Rech.f. & $\begin{array}{l}\text { Tehran: Damavand } \\
\text { Tehran: Rodehen } \\
\text { Golestan, Ramian }\end{array}$ & $\begin{array}{l}38^{\circ} 52^{\prime} 37^{\prime \prime} 47^{\circ} 23^{\prime} 92^{\prime \prime} \\
32^{\circ} 50^{\prime} 03^{\prime \prime} 51^{\circ} 52^{\prime} 08^{\prime \prime} \\
35^{\circ} 50^{\prime} 03^{\prime \prime} 48^{\circ} 52^{\prime} 08^{\prime \prime}\end{array}$ & $\begin{array}{l}1144 \\
1066 \\
1234\end{array}$ \\
\hline $\mathrm{Sp} 2$ & $\begin{array}{l}\text { C. camptocarpa (Fisch. \&C.A.Mey.) } \\
\text { Nevski }\end{array}$ & Khorassan: Sarakhs, $14 \mathrm{~km}$ to Mozduran & $32^{\circ} 50^{\prime} 03^{\prime \prime} 51^{\circ} 24^{\prime} 28^{\prime \prime}$ & 1990 \\
\hline Sp3 & C. lorestanica IRANSHAHR, & $\begin{array}{c}\text { Lorestan: } 110 \mathrm{~km} \text { Khorram abad } \\
\text { Markazi:Arak }\end{array}$ & $\begin{array}{l}29^{\circ} 20^{\prime} 07^{\prime \prime} 51^{\circ} 52^{\prime} 08^{\prime \prime} \\
36^{\circ} 14^{\prime} 14^{\prime \prime} 51^{\circ} 18^{\prime} 07^{\prime \prime}\end{array}$ & $\begin{array}{l}1610 \\
1807\end{array}$ \\
\hline Sp4 & C. leptocarpa Nevski & Golestan: Golestan national park, Mirzabailoo & $38^{\circ} 52^{\prime} 37^{\prime \prime} 47^{\circ} 23^{\prime} 92^{\prime \prime}$ & 1144 \\
\hline Sp5 & C. persica (Boiss.) Grossh. & $\begin{array}{l}\text { Fars: Bamo national park } \\
\text { Fars: Shiraz } \\
\text { Keramn: Jiroft } \\
\text { Zanjan: Abhar }\end{array}$ & $33^{\circ} 57^{\prime} 12^{\prime \prime} 47^{\circ} 57^{\prime} 32^{\prime \prime}$ & 2500 \\
\hline Sp6 & C. aucheri (Boiss.) Iranshahr & Khorassan: Neyshabur & $34^{\circ} 52^{\prime} 37348^{\circ} 23^{\prime} 92^{\prime \prime}$ & 2200 \\
\hline Sp7 & C. anthoroidea (Boiss.) Schrödinger & East Azerbaijan: kaleybar, Cheshme Ali Akbar & $38^{\circ} 52^{\prime} 37347^{\circ} 23^{\prime} 92^{\prime \prime}$ & 1144 \\
\hline Sp8 & C. hohenackeri (Boiss.) Grossh. & $\begin{array}{c}\text { Arak: Komayjan, Pass of Chehregan village, the margin } \\
\text { road }\end{array}$ & $35^{\circ} 50^{\prime} 03^{\prime \prime} 51^{\circ} 24^{\prime} 28^{\prime \prime}$ & 1700 \\
\hline Sp9 & C. stocksiana Nevski & Golestan: Golestan national park, Mirzabailoo & $36^{\circ} 14^{\prime} 14^{\prime \prime} 51^{\circ} 18^{\prime} 07^{\prime \prime}$ & 1807 \\
\hline Sp10 & C. rugulosa Schrödinger & Esfahan: Semirom to Keikha & $32^{\circ} 36^{\prime} 93^{\prime \prime} 51^{\circ} 27^{\prime} 90^{\prime \prime}$ & 2500 \\
\hline Sp11 & C. ambigua (L.) Ball \& Heywood & Tehran: Between Karaj and Eshtehard & $37^{\circ} 07^{\prime} 02^{\prime \prime} 49^{\circ} 44^{\prime} 32^{\prime \prime}$ & 48 \\
\hline Sp12 & C. orientalis (Gray) Schrödinger & Azarbaijan: $20 \mathrm{~km}$ from Jolfa to Marand & $28^{\circ} 57^{\prime} 22^{\prime \prime} 51^{\circ} 28^{\prime} 31^{\prime \prime}$ & 430 \\
\hline Sp13 & C. regalis S.F. Gray & Azarbaijan: Tabriz & $30^{\circ} 07^{\prime} 24^{\prime \prime} 53^{\circ} 59^{\prime} 06^{\prime \prime}$ & 2178 \\
\hline Sp14 & C. oliveriana (DC.)Schrod. & Kermanshah: $31 \mathrm{~km}$ to Ghasre-shirin & $28^{\circ} 57^{\prime} 22^{\prime \prime} 51^{\circ} 28^{\prime} 31^{\prime \prime}$ & 288 \\
\hline Sp15 & C. flava (DC.)Schrod & Khuzestan: Do-gonbadan & $34^{\circ} 46^{\prime} 10^{\prime \prime} 48^{\circ} 30^{\prime} 00^{\prime \prime}$ & 1870 \\
\hline Sp16 & C. trigonelloides (Boiss.) Munz & Fars: Bamo national park & $35^{\circ} 37^{\prime} 77^{\prime \prime} 46^{\circ} 20^{\prime} 25^{\prime \prime}$ & 1888 \\
\hline Sp17 & C. oligantha (Boiss.)Schrod & Ardabil & $33^{\circ} 47^{\prime} 60^{\prime \prime} 46^{\circ} 07^{\prime} 58^{\prime \prime}$ & 1250 \\
\hline Sp18 & C. linorioides (BOIss.) MUNZ, & Esfahan: Ghamishloo protected area & $37^{\circ} 07^{\prime} 02^{\prime \prime} 49^{\circ} 44^{\prime} 32^{\prime \prime}$ & 48 \\
\hline Sp19 & C. rugulosa f. paradoxa (Bunge) Iranshahr & Hamedan: Khan Abad & $28^{\circ} 57^{\prime} 22^{\prime \prime} 51^{\circ} 28^{\prime} 31^{\prime \prime}$ & 288 \\
\hline
\end{tabular}

\section{Random Amplified Polymorphic DNA}

We extracted DNA from fresh leaves. Leaves were dried. DNA extraction was carried out according to the previous protocol (Esfandani-Bozchaloyi et al. 2019; Niu et al., 2021; Sun et al., 2021). DNA quality was checked on an agarose gel to confirm the purity. We amplified the DNA with the aid of RAPD primers (Operon technology, Alameda, Canada). These primers belonged to OPA, OPB, OPC, OPD sets. We selected those primers (10) which could show clear bands and polymorphism (Table 3). Overall, the polymerase chain reaction contained $25 \mu \mathrm{l}$ volume. This 25 volume had ten $\mathrm{mM}$ Tris$\mathrm{HCl}$ buffer, $500 \mathrm{mM} \mathrm{KCl} ; 1.5 \mathrm{mM} \mathrm{MgCl}_{2} ; 0.2 \mathrm{mM}$ of each dNTP; $0.2 \mu \mathrm{M}$ of a single primer; $20 \mathrm{ng}$ genomic DNA and $3 \mathrm{U}$ of Taq DNA polymerase (Bioron, Germany). We observed the following cycles and conditions for the amplification. Five minutes initial denaturation step was carried out at $94^{\circ} \mathrm{C}$ after this forty cycles of 1 minute at $94^{\circ} \mathrm{C}$ were observed. Then 1 -minute cycle was at $52-57^{\circ} \mathrm{C}$ followed by two minutes at $72^{\circ} \mathrm{C}$. In the end, the final extension step was performed for seven to ten minutes at $72^{\circ} \mathrm{C}$. We confirmed the amplification steps while observing amplified products on a gel. Each band size was confirmed according to 100 base pair molecular ladder/standard (Fermentas, Germany).

\section{Data analyses}

Ordination methods such as multidimensional scaling and principal coordinate analysis were also performed (Podani 2000). The morphological difference among species and population was assessed through analysis of variance (ANOVA). PCA analysis (Podani 2000) was done to find the variation in plant population morphological traits. Multivariate and all the necessary calculations were done in the PAST software, 2.17 (Hammer et al. 2001). To assess genetic diversity, we encoded RAPD bands as present and absent. Numbers 1 and 0 were used to show the presence and absence of bands. It is essential to know the polymorphism infor- 


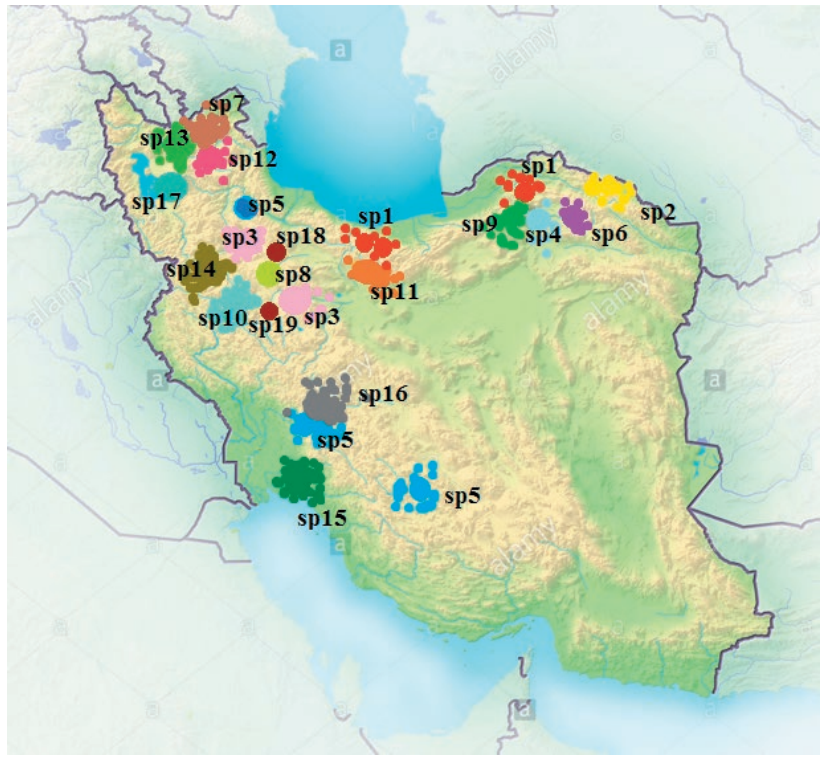

Figure 1. Map of distribtion of populations Consolida species in Iran; $\mathrm{sp} 1=$ C. tehranica; $\mathrm{sp} 2=$ C. camptocarpa; $\mathrm{sp} 3=$ C. lorestanica; $\mathrm{sp} 4=$ C. leptocarpa; $\mathrm{sp} 5=$ C. persica $; \mathrm{sp} 6=$ C. aucheri; $\mathrm{sp} 7=$ C. anthoroidea; $\mathrm{sp} 8=$ C. hohenackeri; $\mathrm{sp} 9=$ C. stocksiana; $\mathrm{sp} 10$ : C. rugulosa; sp11: C. ambigua ; sp12= C. orientalis; $\mathrm{sp13}=$ C. regalis; $\mathrm{sp} 14=$ C. oliveriana; $\mathrm{sp} 15=$ C. flava $; \mathrm{sp} 16=C$. trigonelloides; $\mathrm{sp} 17=C$. oligantha; sp18=C. linorioides; sp19=C. rugulosa f. paradoxa .

mation content and marker index (MI) of primers because these parameters serve to observe polymorphic loci in genotypes (Ismail et al. 2019). Marker index was calculated according to the previous protocol (Heikrujam et al. 2015). Other parameters such as the number of polymorphic bands (NPB) and effective multiplex ratio (EMR) were assessed. Gene diversity associated characteristics of plant samples were calculated. These characteristics include Nei's gene diversity $(\mathrm{H})$, Shannon information index (I), number of effective alleles $(\mathrm{Ne})$, and percentage of polymorphism $(\mathrm{P} \%=$ number of polymorphic loci/number of total loci) (Shen et al. 2017). Unbiased expected heterozygosity (UHe), and heterozygosity were assessed in GenAlEx 6.4 software (Peakall and Smouse 2006). Neighbor-joining (NJ) and networking were studied to fathom genetic distance plant populations (Huson and Bryant 2006; Freeland et al. 2011). The comparison of genetic divergence or genetic distances, estimated by pairwise $\mathrm{F}_{\mathrm{ST}}$ and related statistics, with geographical distances by Mantel test is one of the most popular approaches to evaluate spatial processes driving population structure. The Mantel test was performe as implemented in PAST. For this, Nei genetic distance was determined for RAPD data, while Geographic distance of PAST was determined for geographical data. It is calculated based on the sum of the paired differences among both longitude as well as latitude coordinates of the studied populations (Podani 2000). As we were interested in knowing the genetic structure and diversity, we also investigated the genetic difference between populations through AMOVA (Analysis of molecular variance) in GenAlEx 6.4 (Peakall and Smouse 2006). Gene flow $(\mathrm{Nm})$ which were calculated using POPGENE (version 1.31) program [Yeh et al. 1999]. Gene flow was estimated indirectly using the formula: $\mathrm{Nm}=0 \_25\left(1_{\_}\right.$FST $) /$FST .

We also did STRUCTURE analysis to detect an optimum number of groups. For this purpose, the Evanno test was conducted (Evanno et al. 2005).

\section{RESULTS}

\section{Morphometry}

Significant ANOVA results $(\mathrm{P}<0.01)$ showed differences in quantitative morphological characters in plant species. Principal component results explained $80 \%$ variation. Firs component of PCA demonstrated $57 \%$ of the total variation. Traits such as presence of petiole in caulin leaves, overtopping the bract from fruit, proportion of petal middle lobes to lateral lobes, presence of hair on the filament positively correlated with firs component $(>0.7)$. The second and third components explained characters such as number of petal lobes, position of hair on filament, colour of anther, shape of follicle beak, shape of follicle. Unweighted pair group method with arithmetic mean (UPGMA) and principal component analysis (PCA) plots showed symmetrical results (Figure 2). Generally, plant specimens belonging to different species were separated from each other due to differences in morphology. Our PCA results also confirmed the application of morphological characters in separating and clustering the species in separate groups (Figure 2).

\section{Species identification and genetic diversity}

The primers, i.e., OPD-05, could amplify plant (Consolida ) DNA (Figure 3). 133 polymorphic bands were generated and amplified. Amplified products ranged from 100 to $3000 \mathrm{bp}$. We recorded the highest polymorphic bands for OPA-06. OPD-08 had the lowest polymorphic bands. The average polymorphic bands ranged to 13.3 for each primer. The polymorphic information content (PIC) had values in the range of 0.38 (OPC-04) to 0.57 (OPB-02). Primers had 0.52 average polymorphic information content values.

Marker index (MI) values were 4.18 (OPD-05) to 8.87 (OPA-06), with an average of 6.87 per primer. Effec- 
Table 2. Characters used in this study from Iran.

\begin{tabular}{|c|c|c|c|}
\hline \multirow{2}{*}{$\begin{array}{l}\text { Character } \\
\text { Length of basal leaves }\end{array}$} & \multicolumn{3}{|l|}{ Character states } \\
\hline & $0:<55 \mathrm{~mm}$ & $1:<55 \mathrm{~mm}$ & \\
\hline Number of bracts & 0: 0 & $1: 1$ & $2: 2$ \\
\hline Broad of petal & 0: 3-9 mm & 1: $8-16 \mathrm{~mm}$ & \\
\hline Number of bracteole & 0 : variable & 1: constant & \\
\hline Length of bracteole & $0: \leq 9 \mathrm{~mm}$ & $1: \geq 12 \mathrm{~mm}$ & \\
\hline Length of spure & $0: \leq 25 \mathrm{~mm}$ & $1: \geq 25 \mathrm{~mm}$ & \\
\hline Shape of spure & 0 : curved & 1: erect & \\
\hline Hair on lateral sepal & 0 : scattered & 1: on the middle vein & \\
\hline Number of petal lobes & $0: 5$ & $1: 3$ & \\
\hline Proportion of petal middle lobes to lateral lobes & 0: equal & 1: shorter & 2: longer \\
\hline Hair on the filament & 0 : absent & 1: present & \\
\hline Hair on filament & 0: wing & 1: total of filament & \\
\hline Colour of anther & 0 : brown & 2: yellow & \\
\hline Shape of follicle beak & 0 : erect & 1: curved & \\
\hline Shape of follicle & 0: falciform & 1: erect & \\
\hline Hair on the follicle surface & 0 : absent & 1: present & \\
\hline Shape of fruit stalk & 0 : antrorse & 1: erect & 2: decurved \\
\hline Proportion of pedicle to flower & 0 : shorter & 1: longer & \\
\hline Proportion of pedicle to fruit & 0: shorter & 1: longer & \\
\hline Presence of petiole in caulin leaves & 0 : present & 1 : absent & \\
\hline Presence of hair on the leaf surface & 0 : present & 1: absent & \\
\hline Overtopping the bract from flower & 0:yes & 1: no & \\
\hline Overtopping the bract from fruit & $0:$ yes & 1: no & \\
\hline Position of bract & $0:$ near the flower & 1: far from the flower & \\
\hline Spure & 0 : present & 1: absent & \\
\hline
\end{tabular}

tive multiplex ratio (EMR) values are useful to distinguish genotypes. In our study, we reported 9.34 (OPD08) to 16.55 (OPA-05) EMR values. EMR values averaged 13.57 per primer (Table 3 ). All the necessary genetic features calculated of 19 Consolida species are shown (Table 4). C. linorioides depicted unbiased expected heterozygosity (UHe) in the range of 0.15 . C. orientalis showed a 0.34 . UHe value heterozygosity had a mean value of 0.23 in overall Consolida species. Shannon information was high (0.32) in C. orientalis. C. linorioides showed the lowest value, 0.20. Mean values for Shannon information was 0.22 . The observed number of alleles $(\mathrm{Na})$ ranged from 0.201 to 0.555 in $C$. regalis and C. oligantha. The effective number of alleles $(\mathrm{Ne})$ was in the range of 0.67 1.876 for C. flava and C. leptocarpa.

Analysis of Molecular Variance (AMOVA) test highlighted genetic differences among Consolida species $(\mathrm{P}=$ 0.01). AMOVA revealed significant difference among the studied populations. It also revealed that, $46 \%$ of total genetic variability was due to within population diversi- ty and 54\% was due to among population genetic differentiation (Figure 4). Genetic similarity and dissimilarity assessed through Genetic statistics (GST) showed significant differences i.e., $(0.77, \mathrm{P}=0.001)$ and $\mathrm{D}$ _est values $(0.256, p=0.01)$.

The neighbor-joining tree also revealed two major groups (Figure 5). The neighbor-joining tree also repeated the same pattern as indicated in figures 2 . In current work, molecular findings also coincided with the traditional taxonomical (morphology) approaches for Consolida species.

The neighbor-joining tree divided Consolida species into two groups (Figure 4). Populations belonging to $C$. tehranica; C. camptocarpa; C. lorestanica; C. aucheri; C. rugulosa; $C$. orientalis and $C$. hohenackeri were in the first group. On the other hand, the second group consisted of two sub-groups. C. stocksiana; C. ambigua; C. oliveriana; C. flava formed the first sub-group. C. trigonelloides; C. oligantha; C. linorioides; C. leptocarpa and $C$. persica formed the second sub-group. These groups 
Table 3. RAPD primers and other parameters. Note: TNB - the number of total bands, NPB: the number of polymorphic bands, PPB (\%): the percentage of polymorphic bands, PI: polymorphism index, EMR, effective multiplex ratio; MI, marker index; PIC, polymorphism information content for each of CBDP primers.

\begin{tabular}{lcccccccc}
\hline Primer name & Primer sequence (5'-3') & TNB & NPB & PPB & PIC & PI & EMR & MI \\
\hline OPA-05 & 5'-AGGGGTCTTG-3' & 15 & 15 & $100.00 \%$ & 0.46 & 5.34 & 16.55 & 6.44 \\
OPA-06 & 5'-GGTCCCTGAC-3' & 24 & 24 & $100.00 \%$ & 0.57 & 5.88 & 14.56 & 8.87 \\
OPB-01 & 5'-GTTTCGCTCC-3' & 22 & 22 & $100.00 \%$ & 0.55 & 6.23 & 12.23 & 6.47 \\
OPB-02 & 5'-TGATCCCTGG-3' & 15 & 14 & $91.74 \%$ & 0.57 & 5.66 & 14.56 & 5.67 \\
OPC-04 & 5'-CCGCATCTAC-3' & 13 & 12 & $92.31 \%$ & 0.38 & 3.21 & 15.60 & 5.55 \\
OPD-02 & 5'-GGACCCAACC-3' & 14 & 13 & $97.74 \%$ & 0.37 & 5.66 & 9.56 & 5.67 \\
OPD-03 & 5'-GTCGCCGTCA-3' & 13 & 12 & $92.31 \%$ & 0.54 & 8.21 & 10.23 & 5.55 \\
OPD-05 & 5'-TGAGCGGACA-3' & 12 & 12 & $100.00 \%$ & 0.47 & 7.32 & 11.55 & 4.18 \\
OPD-08 & 5'-GTGTGCCCCA-3' & 11 & 9 & $80.89 \%$ & 0.43 & 6.56 & 9.34 & 7.18 \\
OPD-11 & 5'-AGCGCCATTG-3' & 10 & 10 & $100.00 \%$ & 0.49 & 4.25 & 14.11 & 7.87 \\
Mean & & 14.5 & 13.3 & $96.22 \%$ & 0.52 & 6.32 & 13.57 & 6.87 \\
Total & & 145 & 133 & & & & & \\
\hline
\end{tabular}

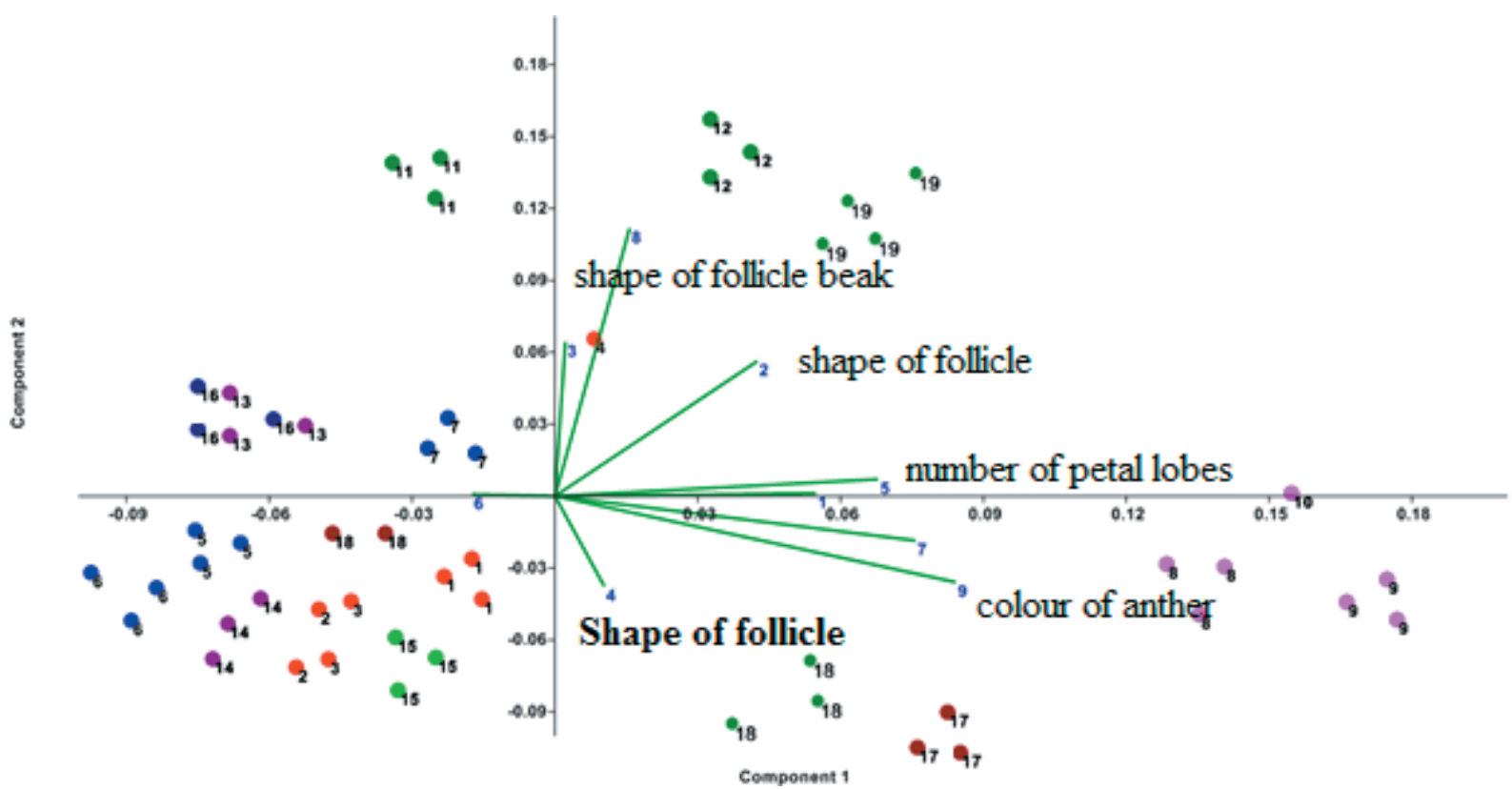

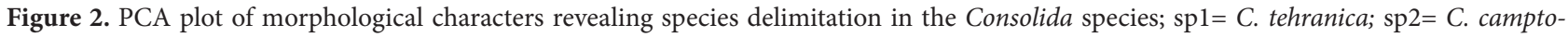
carpa; $\mathrm{sp} 3=$ C. lorestanica; $\mathrm{sp} 4=$ C. leptocarpa; $\mathrm{sp} 5=$ C. persica; $\mathrm{sp} 6=$ C. aucheri; $\mathrm{sp} 7=$ C. anthoroidea; $\mathrm{sp} 8=$ C. hohenackeri; $\mathrm{sp} 9=$ C. stocksi-

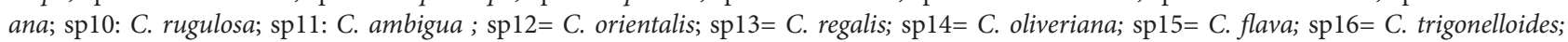
sp17= C. oligantha; sp18=C. linorioides; sp19=C. rugulosa f. paradoxa.

and sub-groups were formed due to molecular differences among the individuals of Consolida.

Gene flow (Nm) was relatively low (0.54) in Consolida species. Genetic identity and phylogenetic distance in the Consolida members are mentioned (Table 5). C. camptocarpa and C. anthoroidea were genetically closely related (0.907) to each other. C. persica and C. rugulosa were dissimilar due to low (0.702) genetic similarity.
Mantel test after 5000 permutations produced significant correlation between genetic distance and geographical distance in these populations $(\mathrm{r}=0.34, \mathrm{P}=0.0002)$. Therefore, the populations that are geographically more distant have less amount of gene flow, and we have isolation by distance (IBD) in Consolida species. The most popular approaches for estimating divergence include calculation of genetic distances and variance partition- 


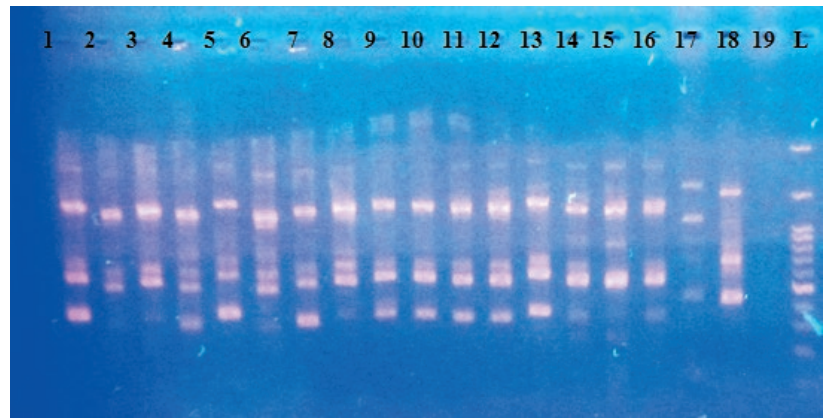

Figure 3. Gel Electrophoresis image of DNA fragments produced by OPD-03 of Consolida species. $\mathrm{sp} 1=$ C. tehranica; $\mathrm{sp} 2=$ C. camptocarpa; $\mathrm{sp} 3=$ C. lorestanica; $\mathrm{sp} 4=$ C. leptocarpa; $\mathrm{sp} 5=$ C. persica; sp $6=C$. aucheri $; \mathrm{sp} 7=C$. anthoroidea $; \mathrm{sp} 8=C$. hohenackeri; $\mathrm{sp} 9=$ C. stocksiana; sp10: C. rugulosa; sp11: C. ambigua; sp12= C. orientalis; sp13=C. regalis; sp14=C. oliveriana; sp15=C. flava; $\mathrm{sp16=}$ C. trigonelloides; $\mathrm{sp} 17=$ C. oligantha; $\mathrm{sp} 18=$ C. linorioides; $\mathrm{sp} 19=\mathrm{C}$. rugulosa f. paradoxa. $\mathrm{L}=$ Ladder $100 \mathrm{bp}$. Arrows show polymorphic bands.

ing among and within populations using Wright's $\mathrm{F}_{\mathrm{ST}}$ and other related statistics, such as $\mathrm{G}_{\mathrm{ST}}, \mathrm{A}_{\mathrm{ST}}, \mathrm{R}_{\mathrm{ST}}, \theta_{\mathrm{ST}}$ and $\Phi_{\mathrm{ST}}$. For instance, the $\mathrm{F}_{\mathrm{ST}}$ gives an estimate of the balance of genetic variability among and within populations, and is an unbiased estimator of divergence between pairs of populations under an island-model in which all populations diverged at the same time and are linked by approximately similar migration rates. However, migration rates usually vary proportionally with geographical distances, so that pairwise $\mathrm{F}_{\mathrm{ST}}$ estimates between pairs of populations vary.

Evanno test performed on STRUCTURE analysis produced the best number of $\mathrm{k}=10$ (Figure.6). The STRUCTURE plot has revealed the allele combination difference among the studied populations and the occurrence of genetic admixture among them.

Inspite of genetic stratification and isolation by distance observed in Consolida species STRUCTURE plot (Figure 7) showed high degree of gene flow among the studied populations, Although the studied populations contained some specific alleles. For example populations 8-14 and 2,19 (differently colored segments in Figure.7), they shared some similar alleles too. For example, it showed genetic similarity between populations 3 and 4 (similarly colored), as well as 5, 6 and 15,16 . The plants of population 1 had some alleles of population 10. Similarly, population 5,6 had some alleles of population 14 .

Nonetheless, we were able to construct a consensus tree that agreed with our molecular (RAPD) and morphological findings (results not shown). The Consolida populations showed divergence due to genetic and morphological characters.

Table 4. Genetic diversity parameters in the studied Consolida species.

\begin{tabular}{|c|c|c|c|c|c|c|c|}
\hline SP & $\mathrm{N}$ & $\mathrm{Na}$ & $\mathrm{Ne}$ & I & $\mathrm{He}$ & $\mathrm{UHe}$ & $\% \mathrm{P}$ \\
\hline C. tehranica & 12.000 & 0.287 & 1.233 & 0.271 & 0.184 & 0.192 & $51.91 \%$ \\
\hline C. camptocarpa & 5.000 & 0.358 & 1.430 & 0.28 & 0.20 & 0.29 & $43.50 \%$ \\
\hline C. lorestanica & 6.000 & 0.299 & 1.029 & 0.231 & 0.18 & 0.23 & $44.38 \%$ \\
\hline C. leptocarpa & 5.000 & 0.462 & 1.876 & 0.288 & 0.29 & 0.28 & $62.05 \%$ \\
\hline C. persica & 8.000 & 0.399 & 1.167 & 0.24 & 0.21 & 0.113 & $52.88 \%$ \\
\hline C. aucheri & 5.000 & 0.336 & 1.034 & 0.23 & 0.25 & 0.19 & $51.83 \%$ \\
\hline C. anthoroidea & 4.000 & 0.344 & 1.042 & 0.28 & 0.23 & 0.27 & $57.53 \%$ \\
\hline C. hohenackeri & 5.000 & 0.455 & 1.234 & 0.277 & 0.24 & 0.22 & $55.05 \%$ \\
\hline C. stocksiana & 3.000 & 0.255 & 1.021 & 0.25 & 0.18 & 0.22 & $42.15 \%$ \\
\hline C. rugulosa & 3.000 & 0.288 & 1.024 & 0.23 & 0.35 & 0.30 & $64.30 \%$ \\
\hline C. ambigua & 5.000 & 0.462 & 1.095 & 0.288 & 0.25 & 0.27 & $62.05 \%$ \\
\hline C. orientalis & 8.000 & 0.399 & 1.167 & 0.322 & 0.398 & 0.344 & $65.77 \%$ \\
\hline C. regalis & 8.000 & 0.201 & 1.00 & 0.23 & 0.17 & 0.17 & $42.23 \%$ \\
\hline C. oliveriana & 5.000 & 0.341 & 1.058 & 0.24 & 0.27 & 0.20 & $53.75 \%$ \\
\hline C. flava & 5.000 & 0.455 & 0.67 & 0.277 & 0.24 & 0.22 & $55.05 \%$ \\
\hline C. trigonelloides & 8.000 & 0.499 & 1.067 & 0.24 & 0.13 & 0.24 & $49.26 \%$ \\
\hline C. oligantha & 6.000 & 0.555 & 1.020 & 0.22 & 0.25 & 0.28 & $43.53 \%$ \\
\hline C. linorioides & 10.000 & 0.431 & 1.088 & 0.20 & 0.12 & 0.15 & $41.53 \%$ \\
\hline C. rugulosa f. paradoxa & 3.000 & 0.255 & 1.021 & 0.25 & 0.18 & 0.22 & $47.15 \%$ \\
\hline
\end{tabular}

Abbreviations: $\mathrm{N}=$ number of samples, $\mathrm{Na}=$ number of different alleles; $\mathrm{Ne}=$ number of effective alleles, $\mathrm{I}=$ Shannon's information index, $\mathrm{He}=$ genetic diversity, $\mathrm{UHe}=$ unbiased gene diversity, $\mathrm{P} \%=$ percentage of polymorphism, populations. 
Table 5. Analysis of molecular variance (AMOVA) of the studied species.

\begin{tabular}{lcccccc}
\hline Source & df & SS & MS & Est. Var. & $\%$ & ФPT \\
\hline Among Pops & 20 & 1701.364 & 55.799 & 12.189 & $54 \%$ & $54 \%$ \\
Within Pops & 120 & 354.443 & 1.905 & 4.55 & $46 \%$ & \\
Total & 150 & 2055.807 & & 16.060 & $100 \%$ & \\
\hline
\end{tabular}

df: degree of freedom; SS: sum of squared observations; MS: mean of squared observations; EV: estimated variance; $\Phi P T$ : proportion of the total genetic variance among individuals within an accession, $(\mathrm{P}<0.001)$.

\section{Percentages of Molecular Variance}

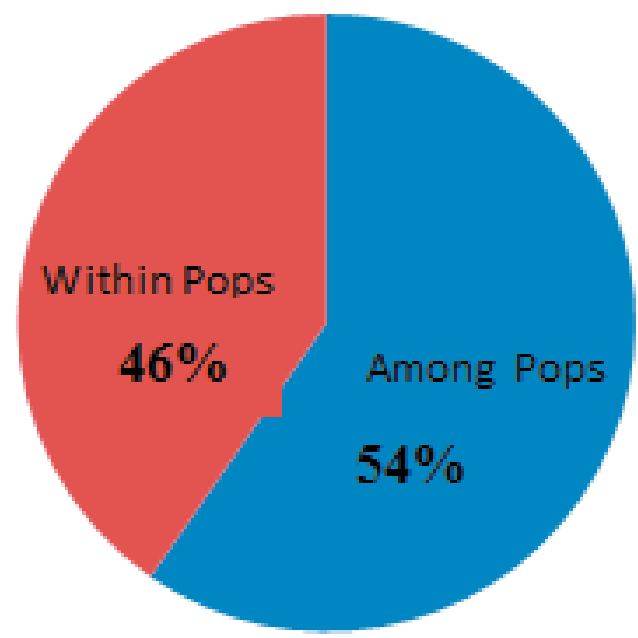

Figure 4. AMOVA test of the studied populations.

\section{DISCUSSION}

The Consolida is a relatively complex taxonomic group, and several morphological characters make it difficult to identify and classify Consolida species (Ertugrul et al., 2016). Given the complexity, it is necessary to explore other methods that could complement the traditional taxonomical approach (Erbano et al. 2015). Advent and developments in molecular techniques have enabled plant taxonomists to utilize molecular protocols to study plant groups (Erbano et al. 2015). Consolida is an evolved genus with precise synapomorphies (reduction of carpels from three or more to one, complete loss of lateral petals, spur consisting of one petal) that are not found in any other species of Delphinium and Aconitum. Most Consolida species are adapted to the Mediterranean type climate or more arid climate types of the

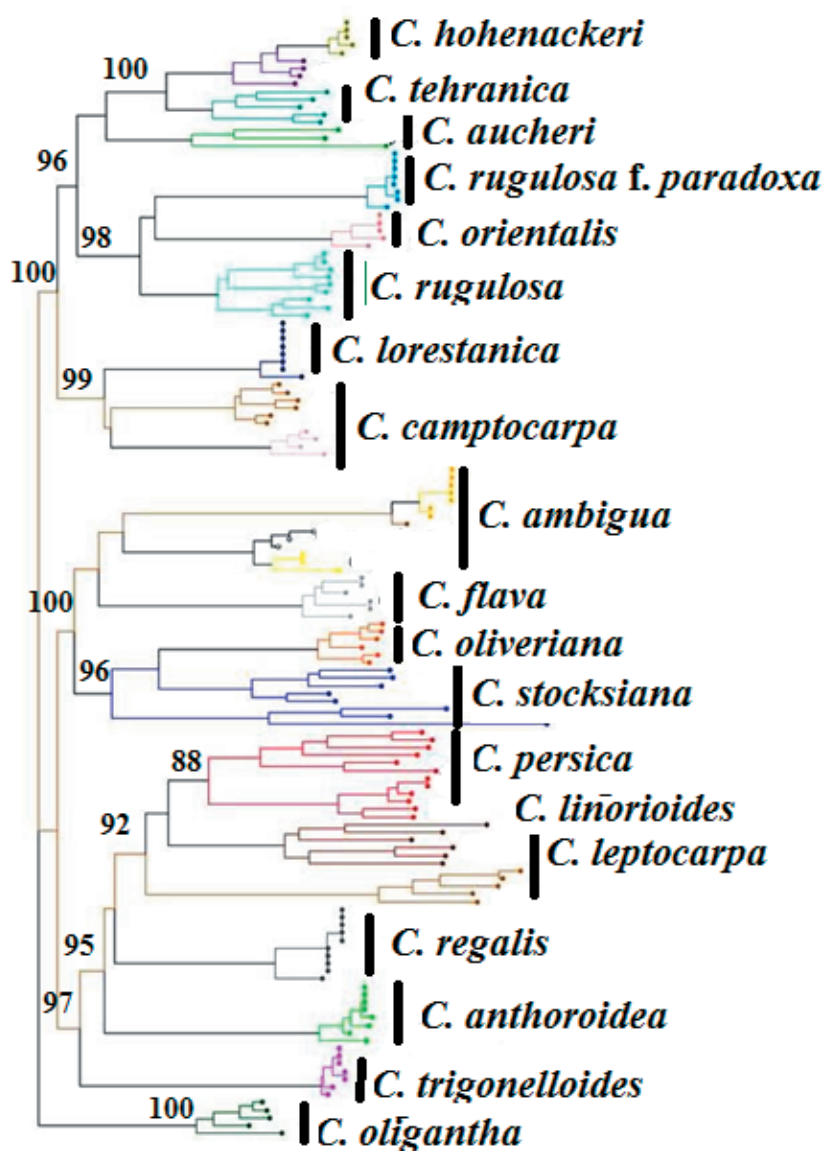

Figure 5. Neigbor-Joingin tree produced while using RAPD data. Branch support values are given as bootstrap (BP) value above branches.

Irano-Turanian zone (Ertugrul et al., 2016). Pronounced periods of drought in these areas have certainly favoured the exclusive annual life cycle of Consolida. The biogeography of the genus indicates that Turkey, in particular Anatolia (c. 29 taxa) should be considered as the center of diversity, with further radiation of species into the Irano-Turanian area (c. 23 taxa), Greece (c. 10 taxa) and countries around the Mediterranean. Consolida forms a coherent, monophyletic clade with Delphinium and Aconitum. Some authors propose a direct evolution line of Consolida from Delphinium (Tamura 1966).

We examined genetic diversity in Consolida by morphological and molecular methods. We mainly used RAPD markers to investigate genetic diversity and genetic affinity in Consolida. Our clustering and ordination techniques showed similar patterns. Morphometry results clearly showed the utilization or significance of morphological characters in Consolida species. PCA results also confirmed the application of morphological characters to separate Consolida species. The present study also high- 


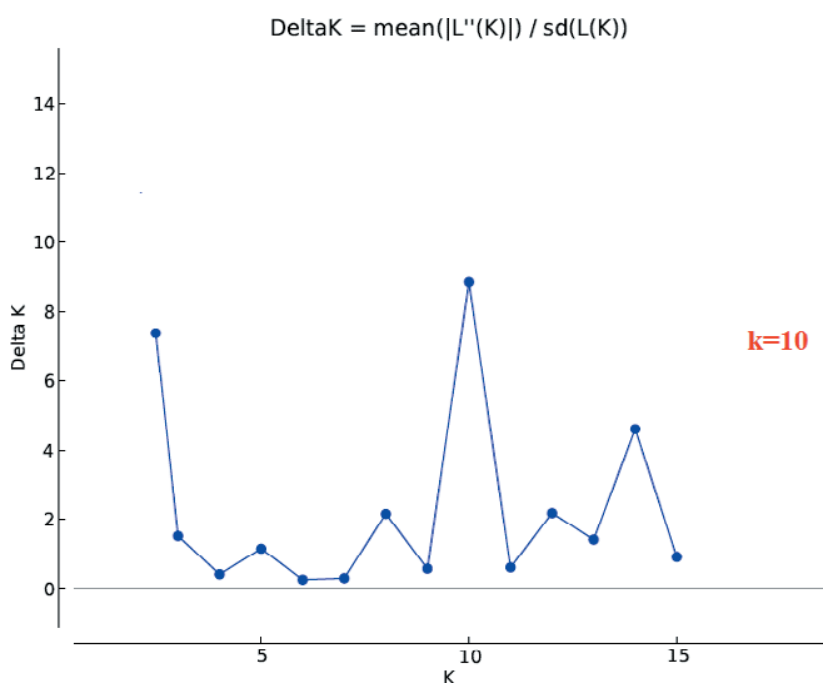

Figure 6. Delta k plot of Evanno's test based on STRUCTURE analysis.

lighted that morphological characters such as bract exerting from fruit, presence of spore, shape of spore apex, the number of petal, the number of petal lobes, could delimit the Consolida group. The Consolida species highlighted morphological differences. We argue that such a dissimilarity was due to differences in quantitative and qualitative traits. Present findings on morphological differences are in line with the previous studies (Iranshahr, 1992; Ertugrul et al., 2016; Khalaj 2013).
Genetic structure and gene flow

Polymorphic information content (PIC) values are useful to detect genetic diversity. The current study recorded average PIC values of 0.52 . This value is sufficient to study genetic diversity in the population (Kempf et al. 2016). High genetic diversity among the Consolida population was reported in the present study. The previous scientific data (Kurata et al. 2019) supports our current high diversity results. Genetic analysis conducted via analysis of molecular variance and STRUCTURE showed genetic differences among the species.

According to Bru"tting et al (2012) sampled 53 populations from 6 arable plant species throughout Central Germany. Random amplified polymorphic DNA analyses (RAPD) were applied to calculate measures of genetic diversity at the population level and genetic differentiation. Their results showed that genetic diversity was found to be lowest in Bupleurum rotundifolium and Anagallis foemina, and highest in Consolida regalis and Nigella arvensis. The highest levels of genetic differentiation were observed among populations of $A n$. foemina and $B$. rotundifolium but within populations in all other species. UST values differed strongly ranging between 0.116 for C. regalis and 0.679 for An. foemina. Patterns of genetic structure were related to the Red List status for all the species studied except An. foemina, for which it should consequently be raised. Them data confirm that even relatively recent threats are accompanied by detrimental genetic structure.

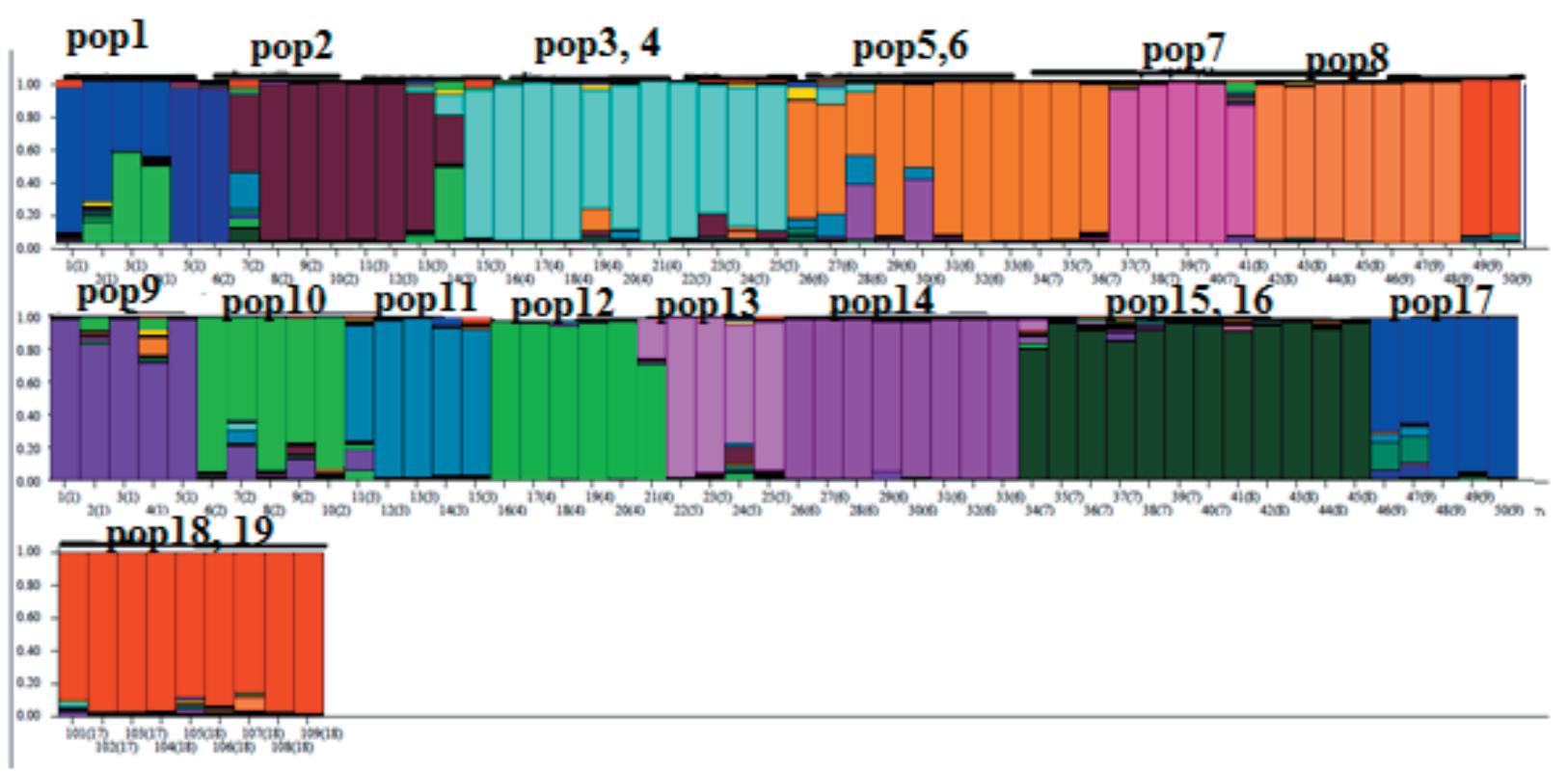

Figure 7. STRUCTURE plot of Consolida species based on $\mathrm{k}=10$ of RAPD data. 
Table 6. The matrix of Nei genetic similarity (Gs) estimates using SCoT molecular markers among 19 Consolida species.sp1= C. tehranica; $\mathrm{sp} 2=$ C. camptocarpa $; \mathrm{sp} 3=$ C. lorestanica $; \mathrm{sp} 4=C$. leptocarpa $; \mathrm{sp} 5=C$. persica $; \mathrm{sp} 6=C$. aucheri; $\mathrm{sp} 7=$ C. anthoroidea; $\mathrm{sp} 8=C$. hohenackeri;

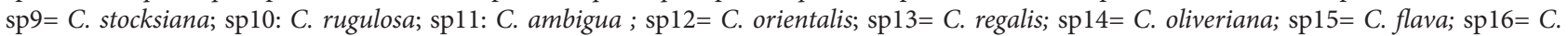
trigonelloides; $\mathrm{sp17}=$ C. oliganth $; \mathrm{sp18}=$ C. linorioides; $\mathrm{sp} 19=$ C. rugulosa f. paradoxa.

\begin{tabular}{|c|c|c|c|c|c|c|c|c|c|c|c|c|c|c|c|c|c|c|c|}
\hline & $\mathrm{sp} 1$ & $\mathrm{sp} 2$ & $\mathrm{sp} 3$ & $\mathrm{sp} 4$ & sp5 & sp6 & sp7 & sp8 & sp9 & sp 10 & sp11 & sp12 & sp13 & sp14 & sp15 & sp16 & sp17 & sp18 & sp19 \\
\hline sp1 & 1.000 & & & & & & & & & & & & & & & & & & \\
\hline $\mathrm{sp} 2$ & 0.896 & 1.000 & & & & & & & & & & & & & & & & & \\
\hline sp3 & 0.858 & 0.813 & 1.000 & & & & & & & & & & & & & & & & \\
\hline $\mathrm{sp} 4$ & 0.846 & 0.836 & 0.842 & 1.000 & & & & & & & & & & & & & & & \\
\hline sp5 & 0.818 & 0.756 & 0.820 & 0.721 & 1.000 & & & & & & & & & & & & & & \\
\hline sp6 & 0.821 & 0.867 & 0.725 & 0.835 & 0.793 & 1.000 & & & & & & & & & & & & & \\
\hline sp7 & 0.814 & 0.907 & 0.834 & 0.750 & 0.836 & 0.862 & 1.000 & & & & & & & & & & & & \\
\hline sp8 & 0.838 & 0.782 & 0.768 & 0.775 & 0.881 & 0.794 & 0.828 & 1.000 & & & & & & & & & & & \\
\hline sp9 & 0.891 & 0.712 & 0.720 & 0.781 & 0.874 & 0.752 & 0.875 & 0.801 & 1.000 & & & & & & & & & & \\
\hline sp10 & 0.826 & 0.798 & 0.854 & 0.759 & 0.702 & 0.742 & 0.770 & 0.754 & 0.880 & 1.000 & & & & & & & & & \\
\hline sp11 & 0.744 & 0.807 & 0.789 & 0.647 & 0.812 & 0.832 & 0.899 & 0.756 & 0.820 & 0.721 & 1.000 & & & & & & & & \\
\hline sp12 & 0.701 & 0.812 & 0.832 & 0.703 & 0.787 & 0.768 & 0.766 & 0.767 & 0.725 & 0.835 & 0.839 & 1.000 & & & & & & & \\
\hline sp13 & 0.734 & 0.712 & 0.720 & 0.881 & 0.852 & 0.797 & 0.849 & 0.807 & 0.834 & 0.750 & 0.799 & 0.642 & 1.000 & & & & & & \\
\hline sp14 & 0.744 & 0.826 & 0.705 & 0.742 & 0.745 & 0.775 & 0.807 & 0.789 & 0.747 & 0.812 & 0.832 & 0.799 & 0.756 & 1.000 & & & & & \\
\hline sp15 & 0.889 & 0.825 & 0.778 & 0.891 & 0.744 & 0.636 & 0.812 & 0.832 & 0.703 & 0.787 & 0.768 & 0.766 & 0.744 & 0.722 & 1.000 & & & & \\
\hline sp16 & 0.743 & 0.838 & 0.739 & 0.738 & 0.787 & 0.768 & 0.712 & 0.720 & 0.881 & 0.852 & 0.797 & 0.649 & 0.807 & 0.797 & 0.891 & 1.0000 & & & \\
\hline sp17 & 0.782 & 0.891 & 0.771 & 0.794 & 0.852 & 0.797 & 0.826 & 0.805 & 0.742 & 0.745 & 0.775 & 0.817 & 0.782 & 0.798 & 0.888 & 0.757 & 1.000 & & \\
\hline sp18 & 0.829 & 0.826 & 0.705 & 0.742 & 0.745 & 0.775 & 0.825 & 0.778 & 0.891 & 0.744 & 0.836 & 0.767 & 0.712 & 0.825 & 0.733 & 0.800 & 0.756 & 1.000 & \\
\hline sp19 & 0.889 & 0.825 & 0.778 & 0.891 & 0.744 & 0.936 & 0.838 & 0.739 & 0.738 & 0.787 & 0.768 & 0.773 & 0.826 & 0.705 & 0.742 & 0.745 & 0.775 & 0.854 & 1.000 \\
\hline
\end{tabular}

\section{Genetic diversity and population size}

Our data suggest that the 19 study species differed highly in their genetic diversity. Populations of C. rugulosa; C. ambigua and C. orientalis showed the highest diversity, followed by C. leptocarpa and C. anthoroidea. Lowest values were found in C. regalis and C. linorioides.

It is widely accepted that the breeding system influences gene diversity dramatically ( Mable and Adam 2007). For example Nybom and Bartish (2004) extracted from literature that selfing taxa have a mean $\mathrm{He}$ of around 0.09 . In contrast, plant species with a mixed or outcrossing breeding system show an $\mathrm{He}$ of around 0.22 to 0.26 . For our study species, C. tehranica; C. camptocarpa; C. lorestanica; C. leptocarpa; C. anthoroidea; C. stocksiana; C. ambigua; C. orientalis and C. regalis tend to have a mixed breeding system and that C. oliveriana; $C$. flava; $C$. trigonelloides are more outcrossing species. This assumption is certainly true for $C$. regalis because it is not self pollinating (Svensson and Wigren 1986). As inflorescences of outcrossing taxa are generally larger than inflorescences of selfing species (Hill et al. 1992), Lower genetic diversity could be an indication of higher fragmentation, as fragmentation leads to limited gene flow (Leimu et al. 2010). In fragmented populations pollinators struggle to reach the more distant popula- tions and may even also decline in abundance (Potts et al. 2010). However, the relationship is consistent with population genetic theory, predicting that genetic drift is particularly important in small populations (Ellstrand and Elam 1993) and population size is positively correlated to genetic variation (Leimu et al. 2006). Molecular markers (RAPD) and morphometry analysis were useful to study genetic diversity and population structure in Consolida species identification. All the species had distinct genetic differentiation. Present results highlighted isolation and limited gene flow are the main deterministic factors that shape the Consolida population. We also reported high genetic diversity, which clearly shows the Consolida species can adapt to changing environments since high genetic diversity is linked to species adaptability.

\section{REFERENCES}

Aitzetmuller K,Tsevegsuren N, Werner F. 1999. Seed oil fatty acid patterns of Aconitum- Delphinium- Helleborous complex (Ranunculaceae). Pl Syst Evol 213: 37-47.

Boissier E. 1841. Voyage botanique dans le midi de l'Espagne, Livraison 16, Vol. 2. Paris: Gide \& Cie. 
Boissier E. 1867. Flora Orientalis, vol. 1. Basel: H. Georg.

Constantinidis T, Psaras GK, Kamari G. 2001. Seed morphology in relation to infrageneric classification of Consolida (DC.) Gray (Ranunculaceae). Flora 196: 81-100.

Cires E, De Smet Y, Cuesta C, Goetghebeur P, Sharrock S, Gibbs D, Oldfield S, Kramer A, Samain M-S. 2013. Gap analyses to support ex situ conservation of genetic diversity in Magnolia, a flagship group. Biodivers Conserv. 22(3):567-590.

Davis PH. 1965. Consolida (DC.) S.F. Gray. Pp. 119-134 in: Davis PH. (ed.), Flora of Turkey and the East Aegean islands, vol. 1, Edinburgh: Edinburgh University Press.

De Candolle AP. 1825. Prodromus Systematis Naturalis Regni Vegetabilis. Vol. 2. Paris, Strasbourg, London.

Ertuğrul K, Arslan E,\& Tugay O. 2010. Characterization of Consolida S.F. Gray (Ranunculaceae) taxa in Turkey by seed storage protein electrophoresis. Turk J Biochem 35: 99-104.

Ellstrand NC, Elam DR. 1993. Population genetic consequences of small population size: implications for plant conservation. Annu Rev Ecol Syst 24:217-242

Ellegren H, Galtier N. 2016. Determinants of genetic diversity. Nat Rev Genet. 17(7):422-433.

Erbano M, Schühli GSE, Santos ÉPD. 2015. Genetic variability and population structure of Salvia lachnostachys: implications for breeding and conservation programs. Int J Mol Sci. 16(4):7839-7850.

Esfandani -Bozchaloyi S, Sheidai M, Keshavarzi M, Noormohammadi Z. 2018c. Morphometric and ISSR-analysis of local populations of Geranium molle L. from the southern coast of the Caspian Sea. Cytol Genet. 52(4):309-321.

Esfandani-Bozchaloyi S, Sheidai M. 2018d. Molecular diversity and genetic relationships among Geranium pusillum and $G$. pyrenaicum with inter simple sequence repeat (ISSR) regions. Caryologia. 71(4):114.

Esfandani-Bozchaloyi S, Sheidai M, Kalalegh M. 2019. Comparison of DNA extraction methods from Geranium (Geraniaceae). Acta Bot. Hung. 61(3-4):251266.

Esfandani-Bozchaloyi S, Sheidai M, Keshavarzi M, Noormohammadi Z. 2018a. Species Relationship and Population Structure Analysis In Geranium Subg. Robertium (Picard) Rouy With The Use of ISSR Molecular Markers. Act Bot Hung. 60(1-2):47-65.

Esfandani-Bozchaloyi S, Sheidai M, Keshavarzi M, Noormohammadi Z. 2018b. Species Identification and Population Structure Analysis In Geranium Subg. Geranium (Geraniaceae). Hacquetia. 17(2):235-246.
Esfandani-Bozchaloyi S, Sheidai M, Keshavarzi M, Noormohammadi Z. 2017.Genetic and morphological diversity in Geranium dissectum (Sec. Dissecta, Geraniaceae) populations. Biologia. 72(10):1121- 1130.

Evanno G., Regnaut S, Goudet J. 2005. Detecting the number of clusters of individuals using the software STRUCTURE: a simulation study. Mol Ecol. 14:2611-2620.

Frankham R. 2005. Stress and adaptation in conservation genetics. J Evol Biol. 18(4):750-755.

Freeland JR, Kirk H, Peterson SD. 2011. Molecular ecology (2nd ed). UK: Wiley-Blackwell.

Gomez A, Vendramin GG, González-Martínez SC, Alia R. 2005. Genetic diversity and differentiation of two Mediterranean pines (Pinus halepensis Mill. and Pinus pinaster Ait.) along a latitudinal cline using chloroplast microsatellite markers. Divers Distrib. 11(3): 257-263.

Gray SF. 1821. A natural arrangement of British plants. vol. 2. London.

Gholamin, R. \& Khayatnezhad, M. 2020a. Assessment of the Correlation between Chlorophyll Content and Drought Resistance in Corn Cultivars (Zea Mays). Helix, 10, 93-97.

Gholamin, R. \& Khayatnezhad, M. 2020b. The effect of dry season stretch on Chlorophyll Content and RWC of Wheat Genotypes (Triticum Durum L.). Bioscience Biotechnology Research Communications, 13, 18331829.

Hayek A. 1970. Prodromus Florae Peninsulae Balcanicae: Im Verlag Von Otto Koeltz, Koenigstein, Taunus, 576 p.

Hong, De-Y. 1986. Biosystematic observation on 5 species of Consolida (Ranunculaceae). Acta Bot Sin 28: 1-10.

Hill JP, Lord EM, Shaw RG (1992) Morphological and growth rate differences among outcrossing and selfpollinating races of Arenaria uniflora (Caryophyllaceae). J Evol Biol 5:559-573

Hasanzadeh F, Kharazian N, Parishani M. 2017. Floristic, Life Form, and Chorological Studies of Saldaran Protected Region, Chaharmahal and Bakhtiari Province, Iran. J Genet Resour 3(2): 113-129.

Hammer O, Harper DAT, Ryan PD. 2001. PAST: paleontological statistics software package for education and data analysis. Palaeontol Electron. 4:9.

Heikrujam M, Kumar J, Agrawal V. 2015. Genetic diversity analysis among male and female Jojoba genotypes employing gene targeted molecular markers, start codon targeted (SCoT) polymorphism and CAAT box-derived polymorphism (CBDP) markers. Meta Gene. 5:90-97.

Huth E. 1895. Monographie der Gattung Delphinium. Bot Jahrb Syst 20: 322-499. 
Huson DH, Bryant D. 2006. Application of phylogenetic networks in evolutionary studies. Mol Biol Evol. 23:254-267.

Han, X., Wei, Z., Zhang, B., Li, Y., Du, T.,... Chen, H. 2021. Crop evapotranspiration prediction by considering dynamic change of crop coefficient and the precipitation effect in back-propagation neural network model. Journal of hydrology (Amsterdam), 596, 126104. doi: 10.1016/j.jhydrol.2021.126104

Ismail NA, Rafii MY, Mahmud TMM, Hanafi MM, Miah G. 2019. Genetic Diversity of Torch Ginger Germplasm Revealed by ISSR and SSR Markers. BioMed Res. 2019:5904804.

Iranshahr M., Rechinger, f., K.H. \& Riedl, H. 1992. Delphinium L. (Ranunculaceae). In: Rechinger KH, (ed) Flora Iranica. no. 171: Akademische Druckund-Verlagsanstalt, Graz, pp. 89-114.

Jing, X., Wang, H., Huang, X., Chen, Z., Zhu, J.,... Wang, X. 2021. Digital image colorimetry detection of carbaryl in food samples based on liquid phase microextraction coupled with a microfluidic thread-based analytical device. Food chemistry, 337, 127971. doi: 10.1016/j.foodchem.2020.127971

Jabbour F, Renner S.S., 2011a. Consolida and Aconitella are an annual clade of Delphinium (Ranunculaceae) that diversified in the Mediterranean basin and the Irano-Turanian region. Taxon. 60, 1029-1040.

Jabbour F. Renner S. 2012 . A phylogeny of Delphinieae (Ranunculaceae) shows that Aconitum is nested within Delphinium and that Late Miocene transitions to long life cycles in the Himalayas and Southwest China coincide with bursts in diversification. Mol Phylogenet Evol 62 928-942.

Jiang, L., Zhang, B., Han, S., Chen, H., \& Wei, Z. 2021. Upscaling evapotranspiration from the instantaneous to the daily time scale: Assessing six methods including an optimized coefficient based on worldwide eddy covariance flux network. Journal of hydrology (Amsterdam), 596, 126135. doi: 10.1016/j.jhydrol.2021.126135

Johansson JT. 1995. A revised chloroplast DNA phylogeny of the Ranunculaceae. Pl Syst Evol (suppl. )9: 253-261.

Koeva T J. 1992. Comparative karyotype treatment of representatives from tribes Delphinieae of subfam. Delphinioideae, Family Ranunculaceae. Ann Univ Sofia 82: 51-61.

Khalaj Z. 2013. Phylogenetic study of the genus Consolida in Iran. Unpublished MSc thesis, Alzahra University, Tehran [In Farsi].

Kemularia-Nathadze L. 1939. Eine neue Ranunculaceengattung Aconitopsis Kem. Nath Trudy Tbilissk Bot Inst. 7: 115-134.
Kempf K, Mora-Ortiz M, Smith LMJ, Kölliker R, Skot L. 2016. Characterization of novel SSR markers in diverse sainfoin (Onobrychis viciifolia) germplasm. BMC Genet. 17(1):124-124.

Kurata S, Sakaguchi S, Ito M. 2019. Genetic diversity and population demography of Geranium soboliferum var. kiusianum: a glacial relict plant in the wetlands of Japan. Conserv Genet. 20(3):431-445.

Khayatnezhad M. Gholamin R. 2020a. A Modern Equation for Determining the Dry-spell Resistance of Crops to Identify Suitable Seeds for the Breeding Program Using Modified Stress Tolerance Index (MSTI). Bioscience Biotechnology Research Communications, 13: 2114-2117.

Khayatnezhad, M. Gholamin, R. 2020b. Study of Durum Wheat Genotypes' Response to Drought Stress Conditions. Helix, 10: 98-103.

Khayatnezhad, M. \& Gholamin, R. 2021a. The Effect of Drought Stress on the Superoxide Dismutase and Chlorophyll Content in Durum Wheat Genotypes. Advancements in Life Sciences, 8: 119-123.

Leimu R, Mutikainen PIA, Koricheva J, Fischer M.2006. How general are positive relationships between plant population size, fitness and genetic variation? J Ecol 94:942-952

Leimu R, Vergeer P, Angeloni F, Ouborg NJ. 2010. Habitat fragmentation, climate change and inbreeding in plants. Ann NY Acad Sci 1195:84-98

Munz PA, 1967b. A synopsis of the Asian species of Consolida (Ranunculaceae). J Arnold Arbor 48: 159-202.

Mable BK, Adam A (2007) Patterns of genetic diversity in outcrossing and selfing populations of Arabidopsis lyrata. Mol Ecol 16:3565-3580

Nybom H. 2004. Comparison of different nuclear DNA markers for estimating intraspecific genetic diversity in plants. Mol Ecol 13:1143-1155.

Jing, X., Wang, H., Huang, X., Chen, Z., Zhu, J.,... Wang, X. 2021. Digital image colorimetry detection of carbaryl in food samples based on liquid phase microextraction coupled with a microfluidic thread-based analytical device. Food chemistry, 337, 127971. doi: 10.1016/j.foodchem.2020.127971

Nevskii SA. 1937. Delphinium L. 79-143 in: Shishkin BK, (ed.), Flora of the U.S.S.R. vol. 7. Moscow, Leningrad: Akademii Nauk SSSR. Translated from Russian.

Potts GR, Ewald JA, Aebischer NJ. 2010a. Long-term changes in the flora of the cereal ecosystem on the Sussex Downs, England, focusing on the years 19682005. J Appl Ecol 47:215-226

Peakall R, Smouse PE. 2006. GENALEX 6: genetic analysis in Excel. Population genetic software for teaching and research. Mol Ecol Notes. 6:288-295. 
Podani J. 2000. Introduction to the exploration of multivariate data [English translation]. Leide (Netherlands): Backhuyes.

Ro, K.-E., Keener, CS. McPheron BA. 1997. Molecular phylogenetic study of the Ranunculaceae: Utility of the nuclear 26S ribosomal DNA in inferring intrafamilial relationships. Mol Phylogenet Evol 8: 117-127.

Sojac J. 1969. Aconitel;la Spach, eine vergessene Gattung der Familie Ranunculaceae. Folia Geobot Phytotax (Praha)4: 447-449.

Soó R. von. 1922. Über die mitteleuropäischen Arten und Formen der Gattung Consolida (DC.) S.F. Gray. Oesterr Bot Z 71: 233-246.

Svensson R, Wigren M.1986. History and biology of Consolida regalis in Sweden. Sven Bot Tidskr 80:31-53

Shen Z, Zhang K, Ma L, Duan J, Ao Y. 2017. Analysis of the genetic relationships and diversity among 11 populations of Xanthoceras sorbifolia using phenotypic and microsatellite marker data. Electron J Biotechnol. 26:33-39.

Sun, S., Xu, L., Zou, Q., Wang, G., \& Gorodkin, J. 2021. BP4RNAseq: a babysitter package for retrospective and newly generated RNA-seq data analyses using both alignment-based and alignment-free quantification method. Bioinformatics, 37(9), 1319-1321. doi: 10.1093/bioinformatics/btaa832

Turchetto C, Segatto ALA, Mäder G, Rodrigues DM, Bonatto SL, Freitas LB. 2016. High levels of genetic diversity and population structure in an endemic and rare species: implications for conservation. AoB Plants. 8:plw002.

Tamura, M. 1966. Morphology, ecology and phylogeny of the Ranunculaceae VI. Sci Rep S Coll N Coll Osaka Univ 15: 13-35.

Trifonova VI. 1990. Comparative biomorphological study of the taxonomy and phylogeny of the genera Consolida (DC.) S.F. Gray and Aconitella Spach. Collect Bot (Barcelona) 19: 97-110.

Tutin TG, Heywood VH, Burges NA, Valentine DH, Walters SM, and Webb D.A, 1964. Flora Europaea, vol. 1-5: Cambridge University Press, Cambridge.

Yeh FC, Yang R, Boyle T 1999. POPGENE. Microsoft Windows-based freeware for population genetic analysis. Release 1.31. University of Alberta 1-31.

Yosefzadeh H, Hosseinzadeh Colagar A Tabari M, Sattarian A, and Assadi M. 2012. Utility of ITS region sequence and structur for molecular identification of Tilia species from Hyrcanian forests, Iran. Plant Sys Evol 298: 947-961 View publication 